\title{
Upaya Meningkatkan Kemampuan Representasi Matematis Siswa dengan Metode Pembelajaran Guided Note Taking Berbantuan Geogebra
}

\author{
Juliana Veva Rahmawati \\ Pendidikan Matematika, FMIPA, Universitas Negeri Jakarta \\ Email penulis: veva4642@gmail.com
}

\begin{abstract}
The ability of mathematical representation is one important aspect that is required to be mastered by students. Through a good representation process, students will be able to find ideas or ideas from a problem that is presented. However, there are still many students who do not have good mathematical representation skills. One of them was found in XI-TEDK 2 SMKN 26 Jakarta students. It might cause students lack self-confidence and positive belief in mathematics. The Guided Note Taking (GNT) method using GeoGebra software might be an alternative learning method that can be used. This type of research is a Classroom Action Research which is conducted in three cycles. Each cycle consists of 4 stages, namely planning, implementing, analyzing and reflecting. There were 34 students who were research subjects at XI-TEDK 2. The GeoGebra-assisted GNT method ended with a final cycle test to measure students' mathematical representation abilities. The results showed that the percentage of students' mathematical representation abilities had increased in each cycle. Cycle I obtained $61.76 \%$, increased to $79.41 \%$ in cycle II and $88.23 \%$ in cycle III. In addition, there is an increase, or at least there is no decrease in the mathematical representation ability of students in each cycle.
\end{abstract}

Keywords: Mathematical Representation ability, Guided Note Taking, GeoGebra.

\begin{abstract}
Abstrak
Kemampuan representasi matematis merupakan salah satu aspek penting yang harus dikuasai peserta didik. Melalui proses representasi yang baik, peserta didik akan mampu untuk menemukan gagasan-gagasan ataupun ide-ide dari suatu permasalahan yang disajikan. Akan tetapi, masih banyak peserta didik yang belum memiliki kemampuan reprsentasi matematis yang baik. Salah satunya dijumpai pada peserta didik XI-TEDK 2 SMKN 26 Jakarta. Hal ini tentunya membuat peserta didik tidak memiliki kepercayaan diri serta keyakinan positif terhadap matematika. Metode Guided Note Taking (GNT) berbantu software GeoGebra dapat menjadi salah satu alternatif pembelajaran yang dapat digunakan. Jenis penelitian ini, merupakan Penelitian Tindakan Kelas (PTK) yang dilakukan dalam tiga siklus. Setiap siklus terdiri dari 4 tahap yaitu perencanaan, pelaksanaan, analisis dan refleksi. Terdapat 34 peserta didik yang menjadi subjek penelitian pada XI-TEDK 2. Metode GNT berbantu GeoGebra diakhiri dengan tes akhir siklus untuk mengukur kemampuan representasi matematis peserta didik. Hasil penelitian menunjukkan bahwa, persentase kemampuan representasi matematis peserta didik mengalami peningkatan di setiap siklusnya. Siklus I memperoleh sebesar $61,76 \%$, meningkat menjadi $79,41 \%$ pada siklus II dan $88,23 \%$ pada siklus III. Selain itu, terjadi peningkatan, atau minimal tidak terjadi penurunan kemampuan representasi matematis peserta didik pada setiap siklusnya.
\end{abstract}

Kata kunci: Kemampuan Representasi Matematis, Guided Note Taking, GeoGebra

Copyright (c) 2021 Rahmawati

$\triangle$ Corresponding author:

Email Address: veva4642@gmail.com

Received 25 Juli 2018, Accepted 24 Februari 2021, Published 28 Februari 2021

\section{PENDAHULUAN}

Kemampuan representasi matematis merupakan salah satu aspek penting yang harus dikuasai peserta didik. Representasi dikatakan sebagai salah satu aspek terpenting bagi peserta didik, karena melalui proses representasi yang baik, peserta didik akan mampu untuk menemukan gagasan-gagasan ataupun ide-ide dari suatu permasalahan yang disajikan. Hal ini tentunya, akan memberikan kemudahan bagi peserta didik dalam menentukan pemecahan masalah yang tepat dalam menyelesaikan soal 
matematika sehingga peserta didik akan memiliki kepercayaan diri serta keyakinan positif terhadap matematika.

Junita (2016) mengartikan representasi matematis sebagai kemampuan seseorang yang diperoleh melalui penglihatan berupa objek-objek matematika untuk selanjutnya dapat digambarkan, dituliskan dan dimodelkan ke dalam bentuk gagasan. Menurut Sulastri, dkk (2017) indikator kemampuan representasi matematis dijabarkan sebagai berikut:

- Menyajikan data atau informasi dari suatu masalah ke representasi gambar, diagram, grafik atau tabel.

- Menyelesaikan masalah yang melibatkan ekspresi matematis.

- Menuliskan langkah-langkah penyelesaian masalah matematika dengan kata-kata atau teks tertulis. Selain itu, kemampuan representasi matematis peserta didik dapat ditentukan berdasarkan kategori yang dikemukakan oleh Armadan, dkk (2017) yakni sebagai berikut :

\begin{tabular}{ll}
\hline NILAI & KATEGORI \\
\hline $\mathbf{8 6 - 1 0 0}$ & Sangat tinggi \\
\hline $\mathbf{7 1 - 8 5}$ & Tinggi \\
\hline $\mathbf{5 6 - 7 0}$ & Sedang \\
\hline $\mathbf{0 - 5 5}$ & Kurang \\
\hline
\end{tabular}

Tabel 1. Kategori Kemampuan Representasi Matematis

Zahro (2016) mengungkapkan bahwa, metode Guided Note Taking mampu membuat peserta didik mengetahui materi yang dibahas dalam pembelajaran, sehingga peserta didik dapat lebih aktif dalam mengemukakan pendapatnya. Metode ini dikembangkan untuk memaksimalkan metode ceramah, sehingga materi yang dibawakan guru lebih mendapat perhatian siswa. Melalui handout yang diberikan, dengan mengosongkan beberapa point-point penting seperti istilah, definisi atau kata kunci, peserta didik tidak hanya mendengarkan penjelasan dari guru, namun peserta didik memiliki tanggung jawab untuk mengisi titik-titik pada handout yang telah diberikan.

Menurut Rahadyan, dkk (2018) GeoGebra merupakan software pendidikan terbaik yang telah mendapatkan 12 penghargaan internasional sejak dirilis pada tahun 2002 hingga 2010, karena mampu melibatkan diantaranya pendekatan analitik, visual dan numerik. GeoGebra memiliki kemampuan untuk memvisualisasikan konsep-konsep matematika secara dinamik sekaligus mampu untuk menyelesaikan masalah matematika baik masalah aritmatika, aljabar, geometri, statistik maupun kalkulus dengan memanfaatkan jendela input dan perintah-perintah yang tersedia.

Menggabungkan penerapan antara metode Guided Note Taking (GNT) dan GeoGebra dianggap sangat sesuai karena mampu untuk memaksimalkan metode ceramah dengan adanya penggunaan handout, dimana peserta didik akan memiliki tanggung jawab untuk mengisi point-point kosong yang ada pada handout. Peserta didik juga akan lebih mudah untuk memvisualisasikan 
permasalahan yang disajikan dengan penggunaan software GeoGebra, sehingga kemampuan representasi matematis peserta didik dapat mengalami peningkatan.

Pelaksanaan pembelajaran metode Guided Note Taking berbantu GeoGebra dilakukan dengan langkah-langkah sebagai berikut:

a. Guru membagikan handout berisi bagian-bagian kosong yang harus diisi peserta didik serta melakukan pengondisian kelas. Handout juga berisikan dengan tujuan pembelajaran dalam rangka memotivasi siswa.

b. Selama proses pembelajaran, guru menyampaikan pentingnya topik serta hasil belajar yang diharapkan dapat tercapai, kemudian menjelaskan materi dengan bantuan GeoGebra, sementara peserta didik mengisi handout-handout berupa materi dan bagian-bagian pada contoh soal yang telah dikosongkan.

c. Peserta didik diberikan tambahan waktu untuk mendiskusikan handout bersama kelompok masingmasing yang terdiri dari 3-4 peserta didik setiap kelompok. Materi pada handout dirancang untuk dapat diselesaikan dengan bantuan GeoGebra.

d. Peserta didik berdiskusi dengan kelompoknya menyelesaikan handout yang telah diberikan guru, berisi materi, contoh soal serta latihan soal dengan bagian-bagian yang telah dikosongkan dengan bantuan GeoGebra.

e. Guru mengarahkan peserta didik untuk dapat menyelesaikan handout dengan menggunakan bantuan GeoGebra.

f. Beberapa peserta didik, yang merupakan perwakilan dari masing-masing kelompok, mempresentasikan hasil diskusi kelompok pada 30 menit terakhir. Sementara, peserta didik lain memperhatikan dan memperbaiki apabila terdapat kekurangan. Kemudian, guru dan peserta didik menyimpulkan pembelajaran yang telah dilaksanakan.

g. Kemudian di akhir pembelajaran akan dilakukan tes akhir siklus selama 45 menit untuk menyelesaikan soal uraian sesuai indikator kemampuan representasi matematis.

Namun pada kenyataannya, kemampuan representasi matematis peserta didik di Indonesia masih jauh dari apa yang diharapkan. Survey terbaru yang dilakukan Programme for International Students Assessment (PISA) pada tahun 2015 untuk kategori sains, membaca, dan matematika dengan melibatkan 540.000 peserta didik di 70 negara, juga menunjukkan bahwa hasil performa peserta didik di Indonesia masih tergolong rendah. Berturut-turut rata-rata skor pencapaian peserta didik Indonesia untuk sains, membaca, dan matematika berada di peringkat 62, 61, dan 63 dari 69 negara yang dievaluasi.

Kemampuan representasi peserta didik yang rendah juga salah satunya terjadi di kelas XI TEDK-2 SMKN 26 Jakarta. Berdasarkan hasil tes kemampuan awal representasi matematis, persentase hasil secara keseluruhan dapat dilihat pada tabel berikut : 


\begin{tabular}{clcc}
\hline No & \multicolumn{1}{c}{ Indikator Representasi Matematis } & No. soal & $\begin{array}{c}\text { Jumlah Persentase Peserta } \\
\text { Didik yang Memperoleh } \\
\text { Skor }\end{array}$ \\
\hline 1. & $\begin{array}{l}\text { Mampu melakukan representasi visual } \\
\text { melalui : } \\
\text { a. Diagram, tabel, atau grafik } \\
\text { b. Gambar }\end{array}$ & 1 & $30,15 \%$ \\
\hline 2. & $\begin{array}{l}\text { Membuat persamaan atau ekspresi } \\
\text { matematis }\end{array}$ & 2 & $56,62 \%$ \\
\hline 3. & $\begin{array}{l}\text { Menyelesaikan masalah matematika dalam } \\
\text { bentuk kata-kata atau teks tertulis }\end{array}$ & 3 & $19,12 \%$ \\
\hline
\end{tabular}

Tabel 1. Hasil Tes Kemampuan Awal Peserta Didik

Berdasarkan latar belakang tersebut, maka akan dilakukan penelitian melalui penelitian tindakan kelas dengan judul "Upaya Meningkatkan Kemampuan Representasi Matematis Peserta Didik Melalui Penerapan Metode Pembelajaran Guided Note Taking dengan Bantuan GeoGebra pada Materi Transformasi Geometri di Kelas XI-TEDK 2 SMKN 26 Jakarta.”

Melihat latar belakang masalah yang diutarakan diatas, maka focus penelitian yang dapat diindetifikasi yakni "Upaya meningkatkan kemampuan representasi matematis peserta didik kelas XI-TEDK 2 SMKN 26 Jakarta menggunakan metode pembelajaran Guided Note Taking berbantu GeoGebra," dengan pertanyaan penelitian sebagai berikut :

1. Bagaimana penerapan metode pembelajaran Guided Note Taking berbantu GeoGebra?

2. Bagaimana respon peserta didik terhadap proses pembelajaran menggunakan metode yang diterapkan?

3. Bagaimana peran guru dalam penerapan metode pembelajaran Guided Note Taking berbantu GeoGebra?

Tujuan yang ingin dicapai dalam penelitian ini adalah untuk meningkatkan kemampuan representasi matematis peserta didik melalui penerapan metode pembelajaran Guided Note Taking berbantu GeoGebra di kelas XI-TEDK 2 SMKN 26 Jakarta.

\section{METODE}

Penelitian ini termasuk penelitian tindakan kelas (PTK). Penelitian bertujuan untuk meningkatkan kemampuan representasi matematis peserta didik melalui penerapan metode Guided Note Taking berbantu GeoGebra di kelas XI-TEDK 2 SMKN 26 Jakarta. Penelitian ini dilaksanakan kepada peserta didik yang berjumlah 34 peserta didik kelas XI-TEDK 2 SMKN 26 Jakarta pada semester genap tahun ajaran 2018-2019 yaitu pada bulan Maret-April 2019.

PTK ini dibantu oleh satu orang participant observer dan dua orang observer. Penelitian tindakan kelas ini dilakukan sampai tiga siklus. Alokasi waktu untuk setiap pertemuan dari setiap siklus adalah 3 jam pelajaran ( 3 x 45 menit) dan tes akhir setiap siklus adalah 1 jam pelajaran (1 x 45 menit). 
Berikut tahapan yang digunakan pada setiap siklusnya:

\section{Siklus I}

1. Tahap Perencanaan

- Menyusun RPP dan LKPD dengan menggunakan metode Guided Note Taking berbantu GeoGebra.

- Mempersiapkan instrumen penunjang lain seperti lembar observasi, soal tes kemampuan serta peralatan dokumentasi.

2. Tahap Pelaksanaan

Pelaksanaan pembelajaran metode Guided Note Taking berbantu GeoGebra dengan langkahlangkah sebagai berikut :

- Guru membagikan handout yang harus diisi peserta didik.

- Selama proses pembelajaran, peserta didik bertugas mengisi handout.

- Peserta didik diberikan tambahan waktu untuk mendiskusikan handout bersama kelompok masing-masing.

- Guru mengarahkan peserta didik untuk dapat menyelesaikan handout dengan menggunakan bantuan GeoGebra.

- Beberapa peserta didik, mempresentasikan hasil diskusi kelompok pada 30 menit terakhir. Sementara, peserta didik lain memperhatikan. Kemudian, guru dan peserta didik menyimpulkan pembelajaran yang telah dilaksanakan.

- Kemudian di akhir pembelajaran dilakukan tes akhir siklus selama 45 menit.

3. Tahap Analisis

Melalui data pengamatan terhadap guru dan peserta didik, serta mencatat semua hal yang terjadi selama proses pembelajaran, kemudian data diolah dan dianalisis.

4. Tahap Refleksi

- Menarik kesimpulan tentang hal-hal yang belum tercapai serta kekurangan yang terdapat pada siklus I.

- Memperbaiki kelemahan pada siklus I, untuk kemudian digunakan sebagai perbaikan pada siklus berikutnya.

\section{Siklus II}

Melaksanakan tahap perencanaan, pelaksanaan, analisis, dan refleksi berdasarkan hasil evaluasi siklus I. Hal-hal yang sudah baik ditingkatkan, sedangkan hal-hal yang masih kurang diperbaiki. Hasil pada siklus II menjadi pedoman melakukan penelitian siklus III.

\section{Siklus III}

Melaksanakan tahap perencanaan, pelaksanaan, analisis, dan refleksi berdasarkan hasil evaluasi siklus II. Hal-hal yang sudah baik ditingkatkan, sedangkan hal-hal yang masih kurang diperbaiki. Refleksi hasil penelitian siklus III dijadikan sebagai bahan penilaian penilaian ketercapaian terhadap 
tindakan penelitian. Apabila terjadi peningkatan dan memenuhi target, maka dapat dikatakan kemampuan representasi matematis peserta didik meningkat. Namun, apabila tidak, perlu dilakukan evaluasi kembali terkait penelitian.

\section{HASIL DAN DISKUSI}

\section{Penerapan Metode Guided Note Taking (GNT) Berbantu GeoGebra}

Terdapat enam langkah metode pembelajaran Guided Note Taking (GNT) dengan bantuan GeoGebra yaitu:

1. Pertama, Guru membagikan handout berisi bagian-bagian kosong yang harus diisi peserta didik. Softcopy Handout selalu dibagikan kepada peserta didik 2 hari sebelumnya, sementara hardcopy handout dibawa pada saat pembelajaran matematika. Hardcopy handout bertujuan untuk membantu peserta didik mengikuti proses pembelajaran. Mengingat peserta didik tidak memiliki buku paket matematika sebagai panduan belajar.

2. Tahapan kedua yakni, selama proses pembelajaran, peserta didik mengisi bagian handout yang telah dikosongkan melalui penjelasan guru. Handout berisi materi beserta contoh-contoh soal yang akan diajarkan pada hari itu. Pada tahapan ini guru juga akan menjelaskan penggunaan software GeoGebra kepada peserta didik.

3. Tahapan ketiga yaitu, peserta didik diberikan tambahan waktu untuk mendiskusikan handout bersama kelompoknya.

4. Tahapan keempat yakni, peserta didik berdiskusi dengan kelompoknya menyelesaikan handout yang telah diberikan oleh guru.

5. Pada tahapan kelima, guru mengarahkan peserta didik untuk dapat menyelesaikan handout.

6. Tahapan terakhir yaitu, perwakilan peserta didik mempresentasikan hasil diskusi kelompok dengan menggunakan bahasa sendiri.

\section{Respon Peserta Didik}

Berikut respon peserta didik mulai dari siklus I sampai dengan siklus III:

1. Pada siklus I materi yang diajarkan yakni refleksi (pencerminan). Masih ada 7 peserta didik yang belum membawa hardcopy handout. Pada siklus I, sebagian peserta didik masih perlu menyesuaikan diri dengan penggunaan handout yang dipakai pada metode Guided Note Taking (GNT) serta toolbar-toolbar yang ada pada software GeoGebra. Berdasarkan hasil yang diperoleh pada tes akhir siklus I, masih ada 13 peserta didik yang belum mampu mencapai indikator keberhasilan yang ditetapkan. Adapun indikator yang telah ditetapkan yaitu, persentase kemampuan representasi matematis peserta didik minimal mencapai kriteria tinggi sebesar $\geq 71$ pada siklus terakhir untuk minimal $\geq 85 \%$ dari total 34 peserta didik. Dimana pada siklus I, persentase yang diperoleh hanya sebesar $61,76 \%$.

2. Pada siklus II, materi yang akan dipelajari yaitu rotasi (perputaran). Sudah banyak peserta didik familiar dengan kata-kata rotasi (perputaran). Pada siklus II, masih ada 4 peserta didik yang belum 
membawa hardcopy handout. Pada siklus II, hampir seluruh peserta didik sudah mampu menyesuaikan diri dengan penerapan metode Guided Note Taking (GNT) berbantu software GeoGebra. Pada siklus II ada 27 peserta didik yang mampu memperoleh kriteria kemampuan representasi matematis $\geq 71$. Ini berarti baru sekitar $79,41 \%$ peserta didik yang berada pada kategori tinggi.

3. Siklus III, peserta didik sudah terbiasa dengan penerapan metode Guided Note Taking (GNT) berbantu software GeoGebra. Materi yang akan dipelajari pada siklus III yaitu dilatasi (perkalian). Pada siklus III seluruh peserta didik sudah membawa hardcopy handout. Peserta didik pada siklus III ini, telah berhasil mencapai kategori tinggi dengan minimal nilai $\geq 71$ sebanyak 30 peserta didik dengan $88,23 \%$. Berikut penilaian representasi matematis yang diperoleh peserta didik XI-TEDK 2 pada siklus I, II dan III.

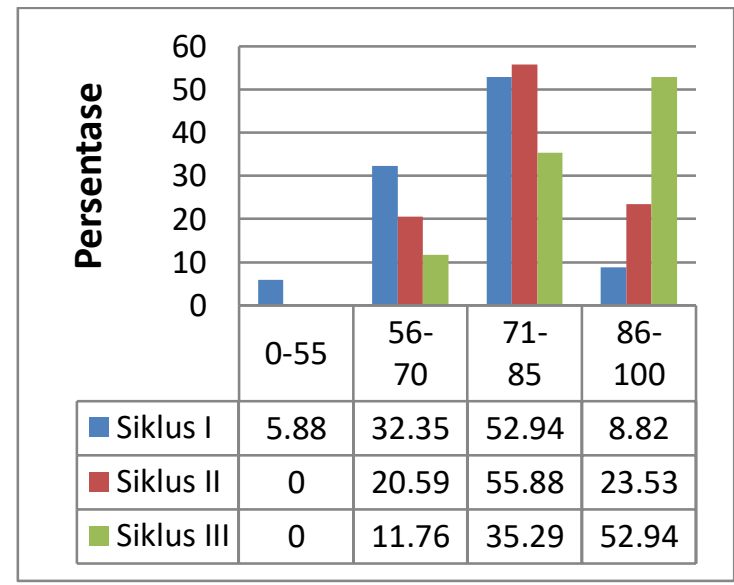

Gambar 1. Diagram Peningkatan Nilai Kemampuan Representasi Matematis Peserta Didik XI-TEDK 2 pada Tes Akhir Siklus I, II, dan III

Gambar diagram 1 di atas merupakan diagram persentase nilai kemampuan representasi matematis peserta didik dari siklus I sampai dengan siklus III. Pada nilai dengan interval 0-55 pada kategori kurang terjadi penurunan sebesar 5.88\% dari siklus I ke siklus II. Interval nilai 56-70 untuk kategori sedang juga mengalami penurunan sebesar $11,76 \%$ dari siklus I ke siklus II, serta penurunan sebesar 8,83\% dari siklus II ke siklus III. Sementara untuk kategori tinggi dengan interval nilai 71-85, terjadi peningkatan sebesar 2,94\% siklus I ke siklus II, dan penurunan dari siklus II ke siklus III sebesar 20,59\%. Pada kategori sangat tinggi dengan interval nilai 86-100 terjadi peningkatan sebesar $14,71 \%$ siklus I ke siklus II, serta peningkatan sebesar 29,41\% siklus II ke siklus III.

\section{Peran Guru}

Guru juga sangat berperan dalam penerapan metode Guided Note Taking (GNT) berbantu GeoGebra dalam proses pembelajaran. Kesiapan guru dalam mengajar juga menjadi salah satu faktor penentu keberhasilan peserta didik dalam menerima materi yang akan diajarkan. Kesiapan guru selalu mengalami peningkatan di setiap siklusnya. Berikut ini merupakan peningkatan kesiapan yang 
dilakukan guru pada setiap siklusnya:

- Siklus I guru belum sempat melakukan review materi serta memberikan motivasi atau penguatan positif kepada peserta didik. Guru bahkan perlu meminjam jam pelajaran guru lain untuk mengejar materi. Peserta didik juga tidak maju kedepan untuk mempresentasikan hasil pekerjaan kelompoknya, melainkan langsung dibahas bersama guru.

- Pembelajaran pada siklus II diawali guru dengan memberikan cerita motivasi tentang tokoh Thomas Alfa Edison. Pemberian motivasi terbukti membuat peserta didik menjadi lebih semangat mengikuti pembelajaran. Manajemen waktu yang dipergunakan pada siklus II ini belum sepenuhnya optimal. Tahapan review yang perlu dilakukan guru belum sempat terlaksana pada tahap ini, karena waktu yang tidak cukup memadai.

- Pembelajaran pada siklus III, seperti pada siklus II, guru juga memberikan motivasi terlebih dahulu kepada peserta didik. Pada siklus III, guru juga telah melakukan pengelolaan manajemen waktu yang jauh lebih baik dibandingkan dengan siklus II. Guru juga sudah melakukan review materi sebelum peserta didik mengerjakan tes akhir siklus.

\section{KESIMPULAN}

Berdasarkan hasil penelitian dan pengamatan, diperoleh kesimpulan sebagai berikut. Kegiatan pembelajaran menggunakan GNT dengan bantuan GeoGebra memiliki enam langkah. Langkah pertama, guru membagikan handout berisi bagian-bagian kosong yang harus diisi peserta didik. Langkah kedua yakni, selama proses pembelajaran, peserta didik mengisi bagian handout yang telah dikosongkan. Langkah ketiga, peserta didik diberikan tambahan waktu untuk mendiskusikan handout bersama kelompoknya. Langkah keempat, yakni, peserta didik berdiskusi dengan kelompoknya menyelesaikan handout yang telah diberikan oleh guru. Langkah kelima, guru mengarahkan peserta didik untuk dapat menyelesaikan handout. Tahapan terakhir yaitu, peserta didik mempresentasikan hasidiskusi kelompok.

Penerapan metode GNT dengan bantuan GeoGebra mendapat respon yang positif dari subjek penelitian juga seluruh peserta didik XI-TEDK 2 SMKN 26 Jakarta. Peserta didik berpendapat bahwa metode GNT berbantu GeoGebra lebih memudahkan dalam meningkatkan kemampuan representasi matematis. GeoGebra membuat gambar yang disajikan lebih nyata dan akurat. Didukung pula oleh tes akhir siklus yang menunjukkan bahwa, persentase kemampuan representasi matematis peserta didik mengalami peningkatan di setiap siklusnya. $61,76 \%$ pada siklus I, meningkat menjadi $79,41 \%$ pada siklus II dan kembali meningkat menjadi $88,23 \%$ pada siklus III.

Guru memegang peran penting dalam terlaksananya pembelajaran Guided Note Taking berbantu GeoGebra. Kesiapan guru merupakan salah satu faktor keberhasilan dalam proses pembelajaran. Siklus I guru belum sempat melakukan review materi serta memberikan motivasi atau penguatan positif kepada peserta didik. Guru bahkan perlu meminjam jam pelajaran guru lain untuk 
mengajarkan materi. Pembelajaran Pada siklus II diawali guru dengan memberikan cerita motivasi tentang tokoh Thomas Alfa Edison. Pemberian motivasi terbukti membuat peserta didik menjadi lebih semangat mengikuti pembelajaran. Manajemen waktu yang dipergunakan pada siklus II ini belum sepenuhnya optimal. Tahapan review juga belum sempat terlaksana.

Pembelajaran pada siklus III, guru juga memberikan motivasi terlebih dahulu kepada peserta didik. Pada siklus III, guru juga telah melakukan pengelolaan manajemen waktu yang jauh lebih baik dibandingkan dengan siklus II. Guru juga sudah melakukan review materi sebelum peserta didik mengerjakan tes akhir siklus. Sejalan dengan meningkatnya kesiapan guru, kemampuan representasi matematis serta antusiasme belajar peserta didik juga ikut meningkat.

\section{REFERENSI}

Andri Rahadyan, Purni Munah Hartuti dan Aulia Ar Rakhman Aawaludin. 2018. Penggunaan Aplikasi GeoGebra dalam Pembelajaran Matematika di Sekolah Menengah Pertama. Jurnal PKM. Volume 1 (1) : 11-19.

Armadan, Somakim dan Indaryanti. 2017. Kemampuan Representasi Matematis Siswa pada Pembelajaran Berbasis Teori Van Hiele di Materi Segiempat Kelas VII SMP Negeri 1 Indralaya Utara. Jurnal Elemen Volume 3 (1) : 49-57.

Iswadi, Hazrul. Sekelumit Dari Hasil PISA 2015 yang Baru Dirilis. (http://ubaya.ac.id/2014/content/articles_detail/230/Overview-of-the-PISA-2015-results-thathave-just-been-Released.html, diakses pada tanggal 25 Juni 2018 pukul 19.00 wib).

Junita, Ranisa. 2016. Kemampuan Representasi dan Komunikasi Matematis Peserta Didik SMA Ditinjau dari Prestasi Belajar dan Gaya Kognitif. Jurnal Pendidikan Matematika Volume 11 (2) : 193-206.

Sulastri, Marwan dan M.Duskri. 2017. Kemampuan Representasi Matematis Siswa SMP Melalui Pendekatan Pendidikan Matematika Realistik. Jurnal Tadris Matematika Volume 10 (1) : 5169.

Zahro, Anis Fathimatus. 2017. Pengaruh Metode Guided Note Taking Didukung Media Grafis Terhadap Kemampuan Mengenal Lembaga-Lembaga Negara dalam Susunan Pemerintah Tingkat Pusat pada Siswa Kelas IV SDN Gayam Kediri Tahun Ajaran 2016/2017. Jurnal Simki-Pedagogia Volume 1 (5) : 1-9. 